[Letter]

\title{
Sulfur Tolerance of Pd, Pt and Pd-Pt Catalysts Supported on Amorphous Silica
}

Takashi Matsui*, Masaru Harada, Kyoko K. Bando, Makoto Toba, and Yuji Yoshimura National Institute of Advanced Industrial Science and Technology, Tsukuba, Ibaraki 305-8565, JAPAN

\author{
(Received February 17, 2004)
}

Effect of pore structure of silica support on sulfur tolerance and tetralin hydrogenation activity of $\mathrm{Pd}, \mathrm{Pt}$ and $\mathrm{Pd}-\mathrm{Pt}$ catalysts was investigated. Pore diameter of $\mathrm{SiO}_{2}$ supports affected the sulfur tolerance of noble metals and resulting hydrogenation activity. High sulfur tolerance and tetralin hydrogenation activity were observed for the $\mathrm{Pd} \cdot \mathrm{Pt}$ and $\mathrm{Pt}$ catalysts supported on $\mathrm{SiO}_{2}$ having the average pore diameter of $3 \mathrm{~nm}$. This sulfur tolerance was comparable to those supported on ultra stable Y (USY) zeolite having the $\mathrm{SiO}_{2} / \mathrm{Al}_{2} \mathrm{O}_{3}$ ratio of 390 .

\section{Keywords}

Noble metal catalyst, Silica support, Pore diameter, Sulfur tolerance, Aromatics hydrogenation

\section{1. 緒言}

ディーゼル排ガス中の粒子状物質(PM)の生成要 因の一つとして、軽油中の多環芳香族炭化水素が指 摘されている 1)。低温作動型の貴金属触媒を用いた 芳香族の低減は熱力学的に有利であるものの、貴金 属は軽油中に含まれる硫黄成分による被毒を受け 易いため、担持貴金属触媒の耐硫黄性強化が課題と なっている 2),3)。耐硫黄性向上の手段として、貴金 属微粒子の含硫黄有機化合物による被毒を、多孔性 担体を用いて形状選択的に防ぐ方法 2)、担体の固体 酸 4),5)または金属の合金化 3)により硫黄と貴金属と の結合を弱める方法がこれまで用いられてきた。し かし、固体酸量が少ないハイシリカ型超安定化 $\mathrm{Y}$ 型(USY)ゼオライトを用いた場合においても、貴金 属微粒子は比較的高い耐硫黄性を示すことが確認 されており 6)、貴金属微粒子の耐硫黄性向上のメカ ニズムについては、未だ不明な点も多い。

本研究では、固体酸や結晶性骨格構造を有しない シリカを担体に用い、USY ゼオライトに近いメソ 細孔を有するシリカと、脱硫触媒用担体として汎用 される $\mathrm{Al}_{2} \mathrm{O}_{3}$ 担体と同等のメソ細孔を有するシリ 力を用いた担持貴金属触媒について、その耐硫黄性 および反応活性の差異を調べ、担体のメソ細孔径が 貴金属触媒の耐硫黄性発現に及ぼす効果について 検討した。

\section{2. 実}

触媒調製：担体は、ハイシリカ型 USY ゼオライ

卜(東ソー製、 $\mathrm{SiO}_{2} / \mathrm{Al}_{2} \mathrm{O}_{3}$ モル比 $=390 、 \mathrm{USY}(390)$ と略記、表面積 $=631 \mathrm{~m}^{2} / \mathrm{g}$ 、メソ細孔表面積 $=71$ $\mathrm{m}^{2} / \mathrm{g}$ 、メソ細孔平均径 $=3.5 \sim 5 \mathrm{~nm}$ )、高比表面積
で平均細孔径の小さいシリカ(富士シリシア製、 $\mathrm{SiO}_{2}(\mathrm{G} 3)$ と略記、表面積 $=655 \mathrm{~m}^{2} / \mathrm{g}$ 、平均細孔径 $=$ $3 \mathrm{~nm}$ )、および低比表面積で平均細孔径の大きいシ リカ(富士シリシア製、 $\mathrm{SiO}_{2}(\mathrm{G} 10)$ と略記、表面積 = $280 \mathrm{~m}^{2} / \mathrm{g}$ 、平均細孔径 $\left.=10 \mathrm{~nm}\right)$ を用いた。パラジ ウムおよび白金の原料にはテトラアンミンパラジ ウム塩化物 $\left(\left[\mathrm{Pd}\left(\mathrm{NH}_{3}\right)_{4}\right] \mathrm{Cl}_{2}\right)$ およびテトラアンミン 白金塩化物 $\left(\left[\mathrm{Pt}\left(\mathrm{NH}_{3}\right)_{4}\right] \mathrm{Cl}_{2}\right)$ を用い、含浸法により粉 末状担体に担持し、乾燥後、粒状 $(310 \sim 710 \mu \mathrm{m})$ に 成形し、酸素気流中 $300^{\circ} \mathrm{C}$ にて焼成した。貴金属担 持量は $1.2 \mathrm{wt} \%$ であり、Pd-Pt バイメタリック触媒 の貴金属原子比は $\mathrm{Pd}: \mathrm{Pt}=4: 1$ とした。貴金属微粒 子径の耐硫黄性に及ぼす影響を避けるため、触媒の 焼成条件を工夫してできるだけ粒子径を揃えたが、 $\mathrm{SiO}_{2}(\mathrm{G} 10)$ では他の担体に比べて分散度が低下した。

触媒特性評価：担持された貴金属微粒子中の表 面露出貴金属の割合を示す分散度 $\left(D_{\mathrm{R}}, \%\right.$ 表示)、お よび粒子径 $\left(d_{\mathrm{p}}\right)$ はパルス式 $\mathrm{CO}$ 吸着法より求めた。 貴金属微粒子の分散度は、 1 貴金属原子に対して $\mathrm{CO}$ 分子一つが結合すると仮定して算出した 7)。調 製した触媒を $300^{\circ} \mathrm{C} に て ~ 1$ 時間水素還元し、貴金属 微粒子の分散度 $\left(D_{\mathrm{R}}\right)$ を測定した。また、 $300^{\circ} \mathrm{C}$ 還元 に引き続き、 $\mathrm{H}_{2} \mathrm{~S}(500 \mathrm{ppm}) / \mathrm{H}_{2}$ 気流中、 $280^{\circ} \mathrm{C}$ で 1 時間硫化処理した触媒の分散度 ( $D_{\mathrm{R} \cdot \mathrm{S}}$ ) を測定し、 貴金属微粒子表面のメタルサイト残存率 $\left(D_{\mathrm{R}-\mathrm{S}} / D_{\mathrm{R}}\right)$ を用いて耐硫黄性の指針とした。

活性試験： テトラリンの水素化反応には高圧固 定床流通式反応装置を用いた（反応温度 $280^{\circ} \mathrm{C}$, 圧 力 $=3.9 \mathrm{MPa}, \mathrm{WHSV}=16 \mathrm{~h}^{-1}$, 原料組成: テトラリン $(30 \%) /$ ○サデカン $(70 \%) / 4,6$-ジメチルジベン

\footnotetext{
“シリカ担持 $\mathrm{Pd} 、 \mathrm{Pt}$ および $\mathrm{Pd}-\mathrm{Pt}$ 触媒の耐硫黄性”

松井高史*、原田 賢、阪東恭子、鳥羽 誠、臀村雄二

（独）産業技術総合研究所 クリーン燃料グループ, 305-8565 茨城県つくば市東 1-1-1 中央第 5

*連絡先、E-mail: takashi.matsui@aist.go.jp
} 
ゾチオフェン $(\mathrm{S}=300 \mathrm{ppm}) /$ ブチルアミン $(\mathrm{N}=20$ $\mathrm{ppm})$ )。反応に先立ち、各触媒は反応管内で $300^{\circ} \mathrm{C}$ で 3 時間、水素還元処理した。水素化活性(HYD) は、触媒活性が安定化した時点(反応開始 50 時間後) におけるテトラリンの転化率から求めた。生成物の 分析は GC-FID を用いて行った。

\section{3. 結果と考察}

分散度から求めた耐硫黄性：Table 1 に各担持 貴金属触媒の分散度を示す。USY(390)ゼオライト 担体の場合、メタルサイトの残存率 $\left(D_{\mathrm{R} \cdot \mathrm{S}} / D_{\mathrm{R}}\right)$ から見 た微粒子表面の耐硫黄性は他の担体より高く、また $\mathrm{Pd} \cdot \mathrm{Pt}$ バイメタリック化によるシナジー効果も認 められた。 $\mathrm{SiO}_{2}(\mathrm{G} 3)$ を担体に用いた場合、貴金属微 粒子の分散度は高く、耐硫黄性はゼオライトよりや や劣るものの、 $\mathrm{Pd}-\mathrm{Pt}$ 触媒では耐硫黄性が $15.5 \%$ と 大幅に向上し、合金化によるシナジー効果が観測さ れた。一方、平均細孔径の大きい $\mathrm{SiO}_{2}(\mathrm{G} 10)$ では、 担持貴金属種によらず分散度 $\left(D_{\mathrm{R}}\right)$ 、および硫化後の メタルサイトの残存率 $\left(D_{\mathrm{R}-\mathrm{S}} / D_{\mathrm{R}}\right)$ が低く、表面の耐硫 黄性の序列は $\mathrm{Pt}>\mathrm{Pd}-\mathrm{Pt}>\mathrm{Pd}$ であった。Pd の耐 硫黄性が著しく低いのはバルク相の硫化が進行し たためと推察した。両シリカ担体の比較より、平均 細孔径が $3 \mathrm{~nm}$ と小さい場合、焼成時の貴金属微粒 子の粒子成長が抑制されるとともに、Pd-Pt の合金 化が促進されると考えられる。

テトラリンの水素化特性：Table 1 の右欄に反応 開始 50 時間後のテトラリン水素化活性(HYD)およ び生成物のデカリンの translcis 比を示す。 $\mathrm{USY}(390)$ を担体に用いた場合、担持 $\mathrm{Pt}$ および $\mathrm{Pd}-\mathrm{Pt}$ 触媒がほぼ同等の高い HYD を示した。ゼオ ライトと表面積や平均細孔径が大きく異なり、耐硫 黄性が低い $\mathrm{SiO}_{2}(\mathrm{G} 10)$ に担持した貴金属触媒の HYD は、全ての貴金属種で低かった。transおよ び cisデカリンの生成比(trans/cis)から見たテトラ リンの水素化選択性の比較から、USY(390)および $\mathrm{SiO}_{2}(\mathrm{G} 3)$ 担体上の $\mathrm{Pd}-\mathrm{Pt}$ バイメタリック微粒子の 表面では、 Pd 相が rich になっていることが示唆さ れた。 $\mathrm{Pt}$ 触媒では trans/cis 比が低く、テトラリン
が Pt 相に強く吸着することが示唆された。

$\mathrm{SiO}_{2}(\mathrm{G} 3)$ を担体とした $\mathrm{Pd} 、 \mathrm{Pt} 、 \mathrm{Pd}-\mathrm{Pt}$ 触媒は USY(390)ゼオライト担体に比べ耐硫黄性はやや劣 るものの、テトラリン水素化活性では USY(390)ゼ オライト担体とそん色のない性能を示した。 $\mathrm{SiO}_{2}(\mathrm{G} 3)$ および USY(390)ゼオライト担体に見ら れる $\mathrm{Pd}-\mathrm{Pt}$ 合金化によるシナジー効果(HYD 活性) は、安田らによる報告 ${ }^{6}$ ほ ど顕著ではなかったが、 本研究では原料中に窒素化合物が含まれているこ とも、その違いに影響していると考えられ、現在検 討中である。 $\mathrm{SiO}_{2}$ (G3)の細孔構造は、USY(390)ゼ オライトの結晶性骨格構造に基づく細孔構造と大 きく異なるが、担持された貴金属微粒子の耐硫黄性 および水素化活性の面での差異は小さい。このこと より、貴金属微粒子と担体との多点接触を通した相 互作用の度合いが増すにつれ、貴金属の電子状態が 変化するためか、耐硫黄性や触媒機能が向上すると 考えられる。 $\mathrm{SiO}_{2}$ 担体はゼオライト担体に比べ、 反応原料中に含まれる塩基性窒素化合物による被 毒を受けにくく、また低価格であり、細孔構造を制 御することにより、Pd-Pt および Pt 系貴金属触媒 の担体としての利用が期待される。

\section{References}

1) Ullman, T. L., SAE paper, No.892072 (1989).

2) Song, C. S., CHEMTECH, 29, 26 (1999).

3) Navarro, R. M., Pawelec, B., Trejo, J. M., Mariscal, R., Fierro, J. L. G., J. Catal., 189, 184 (2000).

4) Gallezot, P., Catal. Rev. -Sci. Eng., 20, 121 (1979).

5) Stanislau, A., Cooper, B. H., Catal. Rev. -Sci. Eng., 36, 75, (1994).

6) Yasuda, H., Sato, T., Yoshimura, Y., Catal. Today, 50, 63, (1999).

7) Yasuda, H., Matsubayashi, N., Sato, T., Yoshimura, Y., Catal. Lett., 54, 23, (1998).

Table 1 Effect of Supports on the Thioresistance and Hydrogenation Activities of Pd, Pt and Pd-Pt Catalysts

\begin{tabular}{ccccccc}
\hline Sample & $\begin{array}{c}D_{\mathrm{R}} \\
{[\%]}\end{array}$ & $\begin{array}{c}d_{\mathrm{p}} \\
{[\mathrm{nm}]}\end{array}$ & $\begin{array}{c}D_{\mathrm{R}-\mathrm{S}} \\
{[\%]}\end{array}$ & $\begin{array}{c}D_{\mathrm{R}-\mathrm{S}} / D_{\mathrm{R}} \\
{[\%]}\end{array}$ & $\begin{array}{c}\text { HYD } \\
{[\%]}\end{array}$ & $\begin{array}{c}\text { trans/cis } \\
{[-]}\end{array}$ \\
\hline $\left.\mathrm{Pt} / \mathrm{SiO}_{2}(\mathrm{G} 10)^{\mathrm{a}}\right)$ & 56.8 & 1.7 & 3.1 & 5.5 & 11.5 & 0.9 \\
$\mathrm{Pd}-\mathrm{Pt} / \mathrm{SiO}_{2}(\mathrm{G} 10)$ & 40.9 & 2.3 & 1.0 & 2.4 & $5.7(3.3)^{\mathrm{c}}$ & 3.8 \\
$\mathrm{Pd} / \mathrm{SiO}_{2}(\mathrm{G} 10)$ & 42.1 & 2.2 & 0.2 & 0.5 & 1.3 & 2.1 \\
\hline $\mathrm{Pt} / \mathrm{SiO}_{2}(\mathrm{G} 3)^{\mathrm{b})}$ & 74.8 & 1.3 & 5.8 & 7.8 & 24.6 & 0.8 \\
$\mathrm{Pd}-\mathrm{Pt} / \mathrm{SiO}_{2}(\mathrm{G} 3)$ & 67.6 & 1.4 & 10.5 & 15.5 & $22.0(13.5)$ & 2.6 \\
$\mathrm{Pd} / \mathrm{SiO}_{2}(\mathrm{G} 3)$ & 65.1 & 1.4 & 5.5 & 8.5 & 10.7 & 2.9 \\
\hline $\mathrm{Pt} / \mathrm{USY}(390)$ & 67.2 & 1.4 & 8.2 & 12.2 & 24.0 & 0.7 \\
$\mathrm{Pd}-\mathrm{Pt} / \mathrm{USY}(390)$ & 55.7 & 1.7 & 9.8 & 17.5 & $24.2(16.0)$ & 2.7 \\
$\mathrm{Pd} / \mathrm{USY}(390)$ & 60.8 & 1.5 & 8.9 & 14.6 & 14.0 & 2.7 \\
\hline $\mathrm{Averapos}$
\end{tabular}

${ }^{a)}$ Average pore diameter of $10 \mathrm{~nm} .{ }^{b}$ Average pore diameter of $\left.3 \mathrm{~nm} .{ }^{\mathrm{c}}\right)$ The values in parentheses indicate the expected activities for the physical mixtures of monometallic $\mathrm{Pd}$ and $\mathrm{Pt}$ catalysts $(4: 1)$. 